\title{
Factors associated with the poor outcomes in diabetic patients with COVID-19
}

Hadith Rastad

Alborz University of Medical Sciences

Hanieh-Sadat Ejtahed

Tehran University of Medical Sciences

Armita Mahdavi-Ghorabi

Tehran University of Medical Sciences

Anis Safari

Alborz University of Medical Sciences

Ehsan Shahrestanaki

Alborz University of Medical Sciences

Mohammad Rezaei

Alborz University of Medical Sciences

Mohammad Mahdi Niksima

Alborz University of Medical Sciences

Akram Zakani

Alborz University of Medical Sciences

Seyede Hanieh Dehghan Manshadi

Alborz University of Medical Sciences

Fatemeh Ochi

Alborz University of Medical Sciences

Shabnam saedi

Alborz University of Medical Sciences

Zeinab Khodaparast

Alborz University of Medical Sciences

Neda Shafiabadi Hassani

Alborz University of Medical Sciences

Mehdi Azimzadeh

Alborz University of Medical Sciences

Mostafa Qorbani ( $\triangle$ mqorbani1379@yahoo.com )

Tehran University of Medical Sciences

\section{Research}

Keywords: diabetes, COVID-19, Mortality, Risk factor

Posted Date: August 12th, 2020 
DOI: https://doi.org/10.21203/rs.3.rs-56358/v1

License: (c) (i) This work is licensed under a Creative Commons Attribution 4.0 International License. Read Full License

Version of Record: A version of this preprint was published at Journal of Diabetes \& Metabolic Disorders on October 9th, 2020. See the published version at https://doi.org/10.1007/s40200-020-00646-6. 


\section{Abstract \\ Background}

Diabetic's patients are supposed to experience higher rates of COVID-19 related poor outcomes. We aimed to determined factors predicting poor outcomes in hospitalized diabetic patients with COVID-19.

\section{Methods}

This retrospective cohort study included all adult diabetic patients with radiological or laboratory confirmed COVID-19 who hospitalized between 20 February 2020 and 27 April 2020 in Alborz province, Iran. Data on demographic, medical history, and laboratory test at presentation were obtained from electronic medical records. Diagnosis of diabetes mellitus was self-reported. Comorbidities including cancer, rheumatism, immunodeficiency, or chronic diseases of respiratory, liver, and blood were classified as "other comorbidities" due to low frequency. The assessed poor outcomes were in-hospital mortality, need to ICU care, and receiving invasive mechanical ventilation. Self-reported. Multivariate logistic regression models were fitted to quantify the predictors of inhospital mortality from COVID-19 in patients with DM.

\section{Results}

Of 455 included patients, 98(21.5\%) received ICU care, 65(14.3\%) required invasive mechanical ventilation, and $79(17.4 \%)$ dead. In the multivariate model, significant predictors of "death of COVID-19" were age 65 years or older (OR (95\% CI): 2.0 (1.16-3.44), chronic kidney disease (CKD) (2.05 (1.16-3.62), presence of "other comorbidities" (2.20 (1.04-4.63)), neutrophil count $\geq 8.0 \times 10 \mathrm{Q} / \mathrm{L}) 6.62$ (3.73-11.7 ((, Hb level < $12.5 \mathrm{~g} / \mathrm{dl}(2.05$ $(1.13-3.72)$ (, and creatinine level $\geq 1.36 \mathrm{mg} / \mathrm{dl}(3.10$ (1.38-6.98)). (All $p$-values < 0.05$)$. Some of these factors were also associated with other assessed poor outcomes, e.g., need to ICU care or invasive mechanical ventilation.

\section{Conclusions}

Diabetic patients with age 65 years or older, comorbidity CKD, "other comorbidities", as well as neutrophil count $\geq 8.0 \times 10 \otimes / \mathrm{L}, \mathrm{Hb}$ level $<12.5 \mathrm{~g} / \mathrm{dl}$, and creatinine level $\geq 1.36 \mathrm{mg} / \mathrm{dl}$, were more likely to dead after COVID-19. Presence of hypertension and cardiovascular disease were associated with none of the poor outcomes.

\section{Background}

The coronavirus 2019 disease (COVID-19) has become to a serious global public health challenge. So far, more than 5.3 million new cases and 342 thousand deaths of COVID-19 has reported worldwide [1]; the pandemic continues to expand despite intensive global preventive efforts. As with previous viral pandemics,[2] patients with underlying conditions are supposed to experience higher rates of COVID-19 related morbidity and mortality [3-5].

Diabetes mellitus (DM) is one of the most common underlying conditions found among patients with COVID-19 $[6,7]$. Besides, the presence of DM has been associated with a higher risk of poor outcome in these patients [8- 
10]. However, up to our knowledge, a few previous studies intended to identify patients' factors on initial presentation that could predict poor outcome in diabetic patients with COVID-19. [11]

Hence, the present study has attempted to ascertain factors associated with poor outcome in hospitalized diabetic patients with COVID-19

\section{Methods}

\section{Study design and population}

This retrospective study included all diabetic patients aged 18 years or older with COVID-19 hospitalized between 20 February 2020 and 27 April 2020 in the Alborz province, Iran. Clinical diagnosis of COVID-19 was confirmed if patients met one of the two following criteria: I) a positive RT-PCR result, or II) a positive pulmonary abnormality on chest CT based on the radiological criteria of COVID-9 infection. We excluded patients who were still hospitalized $(n=19)$. Diabetes was ascertained through self-reporting.

\section{Data collection}

Demographic and clinical characteristics including age, gender, medical history, having any comorbidities, disease symptoms (caught, fever, shortness of breath, tiredness and lack of consciousness), $\mathrm{O}_{2}$ saturation and drug history (statins, angiotensin-converting enzyme inhibitors (ACEIs) and angiotensin II receptor blockers (ARBs)) were collected at the first day of hospitalization. The asked comorbidities included hypertension, cardiovascular disease (CVD), chronic kidney disease (CKD), cancer, chronic liver diseases, psychological disorder, chronic respiratory disease, asthma, thyroid dysfunction, immunodeficiency, autoimmune diseases, hematologic disease, and neurological disorder.

\section{Laboratory testing}

Laboratory parameters on admission (fasting blood glucose level, white blood cell count, lymphocyte count, neutrophil count, concentrations of aspartate and alanine transaminases (AST, ALT), hemoglobin (Hb), creatinine, lactate dehydrogenase (LDH), albumin, erythrocyte sedimentation rate (ESR), C-reactive protein (CRP), creatine phosphokinase (Cpk) and creatine kinase myocardial band (Cpk-MB) were collected.

\section{Outcome}

The primary outcome of this study was in-hospital mortality and poor outcomes including need to intensive care unit (ICU) and being ventilated during hospitalization in COVID-19 patients with diabetes. The study population was classified into two groups: discharged (survivors) or dead (non-survivors). Cured patients were discharged from hospital according to the following criteria: lack of fever for at least $72 \mathrm{~h}$, clinical alleviation, and improvement in pulmonary abnormalities on chest CT imaging.

\section{Statistical analyses}

Descriptive statistics, mean (standard deviation (SD)) or median (interquartile range (IQR)), respectively for continuous variables and frequency (percentage) for categorical variables, were used to summarize 
demographic, clinical, and laboratory data of the cohort. Characteristics of survivors and non-survivors were compared using two-tailed t-tests, Mann-Whitney U tests or Chi-square tests.

The receiver operating curve (ROC) analysis was performed to compare the predictive abilities of blood parameters for predicting death of COVID-19; area under the curve (AUC) and its 95\% confidence interval (Cls) are presented. The optimal cut points that provided the maximum sensitivity and specificity for each blood parameter to predict death of COVID-19 were identified using the maximal Youden Index. Then, the blood parameters were converted into a binary variable based on these identified optimal outpoints. Univariable and Multivariable logistic regression models were used to assess the association of predictor factors with each poor outcomes of COVID-19. Results are presented as crude and adjusted ORs and (95\% Cls). We also performed a log-rank test to determine if there were differences in the survival distribution between males and females and two age groups $\geq 65$ years and $<65$ years.

We considered a P-value of less than 0.05 as statistically significant. We conducted all statistical analyses using SPSS Version19.0, (SPSS Chicago, IL, USA) or STATA version11 (Stata Corp LP, College Station, TX, USA).

\section{Results}

The study population was 455 hospitalized diabetic patients with COVID-19. Table 1 shows characteristics and disease-related symptoms in the study population on admission, overall and by survivor status. Overall, the mean age (SD) of patients was 63.8 (13.5), and 190 (41.8\%) were male. The most common comlaints at prsentaion were shortness of breath (56.7\%), caugh (45.9\%), fever (37.4\%), and tiredness (23.3\%). At admission, lack of consciousness and 02 saturation less than 93\% were observed in $5.7 \%$ (26) and $58.0 \%$ (264) of patients, respectively. Overall, $69.5 \%$ (316) of patients reported at least one comorbidity; the common comorbidities, in order of frequency, were HTN (54.0\%), CVD (43.7\%) and CKD (22.2\%). The use of ACEls /ARBs and statins was reported in $42.9 \%$ (190) and $28.9 \%$ (117) of patients, respectively.

During hospitalization, out of 455 patients, 98(21.5\%) received ICU care, 65(14.3\%) required invasive mechanical ventilation, and 79 (17.4\%) dead. The median time from admission to discharge was 3 days (IQR: 1 - 6 days), and the median time to death was 4 days (2-8 days).

Compared to survivors, patients who dead (non-survivors) were significantly older (mean (SD) age: 69.4 years (12.2) vs. 62.6 years (13.5); $\mathrm{P}<0.001)$, were more likely to have underlying comorbidity CKD (35.4\% (28) vs. $19.4 \%$ (73); $\mathrm{P}=0.002)$. In terms of numbers of comorbidities, a higher percentage of non-survivors had 3 or more comorbidities (22.8 vs. $12.5 \%$; $P=0.008$ ) than survivors.

Non-survivors were more likely to present with lack of consciousness (16.5\% vs. 3.5\%) and 02 saturation less than $93 \%(88.6 \%$ vs. $51.6 \%)$ than survivors. (Both $p$-values $<0.001)$

The frequency of the common complaints, ACEls /ARBs and statins users, also the comorbidities HTN and CVD all were similar between survivors and non-survivors. (All $p$-values $>0.05$ )

Laboratory findings on admission of the study population are presented in Table 2, overall and by survivor status. A lower lymphocyte count (median (IQR): 1.14 (0.78-1.8) vs. 2.25 (1.52-2.87); P-value <0.001), but a higher count of WBC (9.8 (6.7-13.4) vs. 7.1 (5.4-9.2), P-value = 0.004) and neutrophil (8.34 (7.70 -8.71) vs. 7.00 (6.20-7.75); Pvalue $<0.001$ ) was observed in non-survivors compared to survivors. Also, Non-survivors significantly had a 
higher concentration of serum creatinine, CRP, and LDH, CPK, CPK-MB, but a lower concentration of $\mathrm{Hb}$ than survivors (all P-values $<0.05$ ).

Table 3 presents AUC and its 95\% confidence interval (CI) of laboratory parameters for predicting COVID-19 death and optimal cutoff points of these parameters. Among assessed parameters, neutrophil count (AUC ( $95 \% \mathrm{Cl})$ : 0.76 (0.69-0.82)), lymphocyte count (0.75 (0.68-0.81)) and LDH level (0.74 (0.64-0.84)) had the highest diagnostic accuracy for the early detection of COVID-19 death, respectively. Besides, the concentrations of ALT and Esr were non-significant predictors of COVID-19 death.

The optimal cutoff point (sensitivity; specificity) of lymphocyte count, neutrophil count, and LDH level to discriminate between survivors and non-survivors was $1.51 \times 10^{9} / \mathrm{L}(72.1,70.3), 8.0 \times 10^{9} / \mathrm{L}(67.2,74.3)$, and 544 $\mathrm{U} / \mathrm{L}(71.9,72.8)$, respectively.

The WBC count had significantly lower predictive ability compared to neutrophil and lymphocyte count. $(p<0.001)$ Figure 1.

Table 4 presents predictors for poor outcomes of COVID-19 separately, including death, need to ICU care, and invasive mechanical ventilation in diabetic patients based on the results of logistic regression models.

In the multivariate model, significant predictors of "death of COVID-19" were age 65 years or older (OR (95\% CI): 2.0 (1.16-3.44), comorbidity CKD (2.05 (1.16 -3.62), presence of other comorbidity (2.20 (1.04-4.63)), neutrophil count $\geq 8.0 \times 10 \otimes / \mathrm{L}) 6.62$ (3.73-11.7 ((, Hb level <12.5 g/dl (2.05 (1.13-3.72(, and creatinine level $\geq 1.36 \mathrm{mg} / \mathrm{dl}$ (3.10 (1.38-6.98)). (All $p$-values $<0.05)$

Patients with age $\geq 65$ years, 2 or more comorbidities, lymphocyte count $<1.51 \times 10 \mathbb{Q} / \mathrm{L}$, neutrophil count $\geq$ $8.0 \times 10 \otimes / \mathrm{L}, \mathrm{Hb}$ level $<12.5 \mathrm{~g} / \mathrm{dl}$, AST level $\geq 39 \mathrm{U} / \mathrm{L}$, creatinine level $\geq 1.36 \mathrm{mg} / \mathrm{dl}$, LDH level $\geq 544 \mathrm{U} / \mathrm{L}$, and Cpk level $\geq 81.4 \mathrm{U} / \mathrm{L}$ had significantly higher odds for requiring ICU care than others. (All $p-$ values $<0.05$ )

Also, patients with age 65 years or older, comorbidity CKD, neutrophil count $\geq 8.0 \times 10 \rrbracket / L$, AST level $\geq 39 \mathrm{U} / \mathrm{L}$, creatinine level $\geq 1.36 \mathrm{mg} / \mathrm{dl}$, LDH level $\geq 544 \mathrm{U} / \mathrm{L}$ were more likely to require invasive mechanical ventilation than others. (All $p$-values $<0.05$ )

Based on log-rank test results, the difference in the survival distributions between two age groups $\geq 65$ years and $<65$ years were statistically significant $(\chi 2(1)=8.73, p=0.003)$; but, the differences between males and females did not reach statistical significance $(X 2(1)=2.88, p=0.09)$.

\section{Discussion}

In this retrospective observational study, we compared the characteristics of hospitalized diabetic patients with COVID-19 between survivors and non-survivors and investigated the predicting factors for poor outcomes including need to ICU care and invasive mechanical ventilation and in-hospital death.

Based on our results, age 65 years or older, neutrophil count $\geq 8.0 \times 10 \otimes / \mathrm{L}$, and creatinine level $\geq 1.36 \mathrm{mg} / \mathrm{dl}$ were significant predictors for all poor outcomes of COVID-19 including need to ICU care, invasive mechanical ventilation, and death in diabetic patients. Among predictors of COVID-19 death, $\mathrm{Hb}$ level $<12.5 \mathrm{~g} / \mathrm{dl}$ and the presence of comorbidity CKD were also associated with need to ICU care and invasive mechanical ventilation, 
respectively. However, AST level $\geq 39 \mathrm{U} / \mathrm{L}$, LDH level $\geq 544 \mathrm{U} / \mathrm{L}$, Cpk level $\geq 81.4 \mathrm{U} / \mathrm{L}$, lymphocyte count $<1.51 \times$ $108 / L$, were associated with need to ICU care and / or invasive mechanical ventilation but not with COVID-19 death.

Shi et al. also observed infected patients with diabetes who died were older, were more likely to have hypertension and CVD and presented more dyspnea compared with survivors although frequency of CKD was probable between groups [11]. It should be noted that there were no significant difference in frequency of hypertension and CVD as well as percentage of ACEls/ARBs and statins consumption between survivors and non-survivors in our study. Contrary to the recent hypothesis which related severity of COVID-19 infection to elevated expression of ACE2 in those treated with ACEI/ARB drugs [12-14], we did not observe any significant differences in use of these drugs between survivor and non-survivor groups.

According to the laboratory findings, non-survivors had lower lymphocyte count and higher counts of WBC and neutrophil besides higher concentration of serum creatinine, CRP, LDH, CPK and CPK-MB, but lower concentration of $\mathrm{Hb}$ compared to survivors, reflecting severe inflammatory response and cardiac and renal impairments in nonsurvivors. Our findings were in agreement with previous observations in COVID-19 patients [11, 15-17]. These biochemical abnormalities point to that covid-19 infection may be lead to progressive systemic injuries and consequently death in diabetic patients. The mechanisms linking diabetes with high risk of mortality were pulmonary dysfunction and deleterious inflammation which has been indicated in results of comparison between survivors and non-survivors $[15,18]$. Chen et al. indicated CRP as the only risk factor for mortality in diabetic patients with COVID-19 as a clinical manifestation of systemic inflammation [19]. This imbalance between proinflammation and anti-inflammation process could partly explained the reported association between diabetes and low pulmonary function [20].

Regard to baseline FBS, concentration of blood glucose was higher in non-survivors in comparison with survivors, although it is not statistically significant, it has clinically importance. Zhu et al. retrospectively studied nearly 1000 COVID-19 patients with diabetes in China; they showed that fatality rate in patients with well-controlled blood glucose (1.1\%) was lower compared to patients with poorly-controlled blood glucose (11\%). Patients with good glycemic control had lower incidence of ARDS, multi-organ injuries and septic shock relative to the patients with poor glycemic control [21]. Glycemic variability was indicated as a probable predictor for severe complications and mortality in COVID-19 infected patients with diabetes. It has been reported that hyperglycemia may reduce the defensive capacity of respiratory tract through increasing glucose level in airway epithelial secretions [22] as well as increase risk of mortality in infected patients via overproduction of advanced glycation end products and dysfunction of immunoglobulins [23]. Moreover, Covid-19 which was reported to bind ACE2 receptor, may damage pancreatic function and lead to worse glycemic status via binding to this receptor in pancreas $[15,24]$.

Previous studies have been indicated diabetes as a risk factor for poor outcomes and high fatality in COVID-19 patients $[8,25,26]$; however no study focused on biochemical indicators as predicting factors for death in diabetic infected patients, presenting the optimal cutoff points to discriminate between survivors and nonsurvivors. Among laboratory parameters for predicting death, neutrophil and lymphocyte count as indicators for immune function and LDH level as a marker of tissue breakdown had the highest diagnostic accuracy in infected diabetic patients. 
According to the results of logistic regression models, older age, CKD, high neutrophil count and creatinine level were significant predictors of death, requiring ICU care and invasive mechanical ventilation. Moreover, low lymphocyte counts and high LDH and Cpk level were associated with higher odds of ICU care. Our observations were in line with previous findings as Shi et al. declared advanced age as an independent risk factor for inhospital death among COVID-19 patients with diabetes [11]. Totally, old age was demonstrated as an independent predictor of death in COVID-19 patients due to age-dependent decrease in immune function as we observed more lymphopenia in critically ill patients too $[27,28]$. Concordant with previous studies, lymphopenia has been shown as a key characteristic of COVID-19 infection, specifically in critically ill and deceased patients $[16,29]$. Furthermore, it should be noted that diabetes has additive destructive effects on innate and adaptive immunity [30]. Moreover, our results showed that underlying comorbidities like CKD could be associated with poor outcomes in patients with diabetes. Therefore, diabetic patients with underlying renal failure should attract more attention.

The present study is among the first studies with the approach of exploring the predictors of poor prognosis and mortality in COVID-19 patients with diabetes. Due to the retrospective nature of this study, it has some limitations. First, we could not retrieve the pre-hospital status of diabetic patients including their glycemic control which could be significantly associated with numerous clinical risk factors for the poor outcomes. Therefore, the confounding effects of these factors cannot be excluded. Also, given this lack of pre-hospital data, it was not possible for us to access the trend of blood glucose change. Second, participants of this study were relatively severe cases which needed hospitalization. Therefore, the rate of mortality was higher to some extent and might influence the interpretation of the results. Third, we did not consider the drugs which have been used for COVID-19 treatment during hospitalization in analysis. So we cannot rule out its confounding effects. Moreover, we missed the data about antidiabetic treatments of patients which might lead to bias in analysis and interpretation, as indicated by Chen et al. that insulin users had poor prognosis of COVID-19 [19]. Furthermore, there is also discussion on harmful effects of some oral hypoglycemic agents such as Sodium-Glucose-Transporter-2 inhibitors versus beneficial effects of metformin on COVID-19 infected individuals with diabetes [31, 32]. Therefore, further studies investigating impact of different glucose-lowering medications on infected diabetic patients are warranted.

\section{Conclusion}

We demonstrate a guide identifying predicting factors and their cutoff points for poor outcomes including need to ICU care and invasive mechanical ventilation and in-hospital death in admitted COVID-19 patients with diabetes. These risk factors could be considered by clinicians to pay special attention to high-risk patients.

\section{Abbreviations}

DM: Diabetes mellitus; ACEls:angiotensin-converting enzyme inhibitors; ARBs:angiotensin II receptor blockers; CVD:cardiovascular disease; CKD:chronic kidney disease; AST:aspartate transaminase; ALT:alanine transaminases; Hb:hemoglobin; LDH:lactate dehydrogenase; ESR:erythrocyte sedimentation rate; CRP:C-reactive protein; Cpk:creatine phosphokinase; Cp-MB:creatine kinase myocardial band; ICU:intensive care unit; SD:standard deviation; IQR:interquartile range; ROC:receiver operating curve; AUC:under the curve; Cis:confidence interval; HTN:Hypertension; PT:Prothrombin time; WBC:White blood cell; ACEls:angiotensin-converting enzyme inhibitors; ARBs:angiotensin II receptor blockers 


\section{Declarations}

\section{Acknowledgements:}

We acknowledge all persons that help us in data gathering.

\section{Authors' contributions:}

$\mathrm{HR}, \mathrm{H}-\mathrm{SE}$ and MQ had the idea for and designed the study and had full access to all of the data in the study and take responsibility for the integrity of the data and the accuracy of the data analysis. HR, H-SE, AS and ESh drafted the paper. AZ, MN, SH-DM, FO, ShS, Zkh, and NShH collected the MM, and MQ did the analysis, and all authors critically revised the manuscript for important intellectual content and gave final approval for the version to be published. All authors agree to be accountable for all aspects of the work in ensuring that questions related to the accuracy or integrity of any part of the work are appropriately investigated and resolved.

\section{Funding}

Alborz University of Medical Sciences

\section{Availability of data and materials}

The data are available from the corresponding author on a reasonable request.

\section{Ethics approval and consent to participate}

This study was performed according to the Declaration of Helsinki guidelines. Research and Ethics Committee of Alborz University of Medical Sciences (ABZUMS) approved the present research and waived the requirement for informed consent.

\section{Consent for publication}

Not applicable.

\section{Competing interests}

The authors declare no conflict of interest

\section{References}

1. COVID-19 CORONAVIRUS PANDEMIC [https://www.worldometers.info/coronavirus/? utm_campaign=homeAdvegas1?\%20]

2. Monto AS: Epidemiology of influenza. Vaccine 2008, 26:D45-D48.

3. Vincent J-L, Taccone FS: Understanding pathways to death in patients with COVID-19. Lancet Respir Med. 2020;8(5):430-432.

4. Fang L, Karakiulakis G, Roth M: Are patients with hypertension and diabetes mellitus at increased risk for COVID-19 infection? Lancet Respir Med 2020; 8(4):e21. 
5. Huang Y, Lu Z, Li R, Wang B: Does comorbidity increase the risk of patients with COVID-19: evidence from meta-analysis. Aging 2020, 12(7):6049-6057.

6. Ma Y, Diao B, Lv X, Zhu J, Liang W, Liu L, Bu W, Cheng H, Zhang S, Yang L et al: 2019 novel coronavirus disease in hemodialysis (HD) patients: Report from one HD center in Wuhan, China. medRxiv 2020.

7. Edagawa S, Kobayashi F, Kodama F, Takada M, Itagaki Y, Kodate A, Bando K, Sakurai K, Endo A, Sageshima $\mathrm{H}$ : Epidemiological features after emergency declaration in Hokkaido and report of 15 cases of COVID-19 including 3 cases requiring mechanical ventilation. Global Health \& Medicine 2020.

8. Guo W, Li M, Dong Y, Zhou H, Zhang Z, Tian C, Qin R, Wang H, Shen Y, Du K: Diabetes is a risk factor for the progression and prognosis of COVID-19. Diabetes Metab Res Rev.

9. Roncon L, Zuin M, Rigatelli G, Zuliani G: Diabetic patients with COVID-19 infection are at higher risk of ICU admission and poor short-term outcome. J Clin Virol:104354.

10. Zheng Z, Peng F, Xu B, Zhao J, Liu H, Peng J, Li Q, Jiang C, Zhou Y, Liu S: Risk factors of critical \& mortal COVID-19 cases: A systematic literature review and meta-analysis. J Infect 2020.

11. Shi Q, Zhang X, Jiang F, Zhang X, Hu N, Bimu C, Feng J, Yan S, Guan Y, Xu D et al: Clinical Characteristics and Risk Factors for Mortality of COVID-19 Patients With Diabetes in Wuhan, China: A Two-Center, Retrospective Study. Diabetes Care 2020:dc200598.

12. Fang L, Karakiulakis G, Roth M: Are patients with hypertension and diabetes mellitus at increased risk for COVID-19 infection? Lancet Respir Med 2020, 8(4):e21.

13. Li XC, Zhang J, Zhuo JL: The vasoprotective axes of the renin-angiotensin system: Physiological relevance and therapeutic implications in cardiovascular, hypertensive and kidney diseases. Pharmacol Res 2017, 125(Pt A):21-38.

14. Wan Y, Shang J, Graham R, Baric RS, Li F: Receptor Recognition by the Novel Coronavirus from Wuhan: an Analysis Based on Decade-Long Structural Studies of SARS Coronavirus. J Virol. 2020, 94(7):e00127-00120.

15. Yan Y, Yang Y, Wang F, Ren H, Zhang S, Shi X, Yu X, Dong K: Clinical characteristics and outcomes of patients with severe covid-19 with diabetes. BMJ Open Diabetes Res Care. 2020, 8(1):e001343.

16. Yang X, Yu Y, Xu J, Shu H, Liu H, Wu Y, Zhang L, Yu Z, Fang M, Yu T: Clinical course and outcomes of critically ill patients with SARS-CoV-2 pneumonia in Wuhan, China: a single-centered, retrospective, observational study. Lancet Respir Med. 2020; 8(5):475-481.

17. Wang D, Hu B, Hu C, Zhu F, Liu X, Zhang J, Wang B, Xiang H, Cheng Z, Xiong Y: Clinical characteristics of 138 hospitalized patients with 2019 novel coronavirus-infected pneumonia in Wuhan, China. Jama 2020, 323(11):1061-1069.

18. Klein OL, Aviles-Santa L, Cai J, Collard HR, Kanaya AM, Kaplan RC, Kinney GL, Mendes E, Smith L, Talavera G: Hispanics/Latinos with type 2 diabetes have functional and symptomatic pulmonary impairment mirroring kidney microangiopathy: findings from the Hispanic Community Health Study/Study of Latinos (HCHS/SOL). Diabetes care 2016, 39(11):2051-2057.

19. Chen Y, Yang D, Cheng B, Chen J, Peng A, Yang C, Liu C, Xiong M, Deng A, Zhang Y: Clinical Characteristics and Outcomes of Patients With Diabetes and COVID-19 in Association With Glucose-Lowering Medication. Diabetes Care 2020.

20. Giovannelli J, Trouiller P, Hulo S, Chérot-Kornobis N, Ciuchete A, Edmé J-L, Matran R, Amouyel P, Meirhaeghe A, Dauchet L: Low-grade systemic inflammation: a partial mediator of the relationship between diabetes and 
lung function. Ann Epidemiol 2018, 28(1):26-32.

21. Zhu L, She Z-G, Cheng X, Qin J-J, Zhang X-J, Cai J, Lei F, Wang H, Xie J, Wang W: Association of blood glucose control and outcomes in patients with COVID-19 and pre-existing type 2 diabetes. Cell Metab 2020.

22. Philips BJ, Meguer J-X, Redman J, Baker EH: Factors determining the appearance of glucose in upper and lower respiratory tract secretions. Intensive care med 2003, 29(12):2204-2210.

23. Arnold JN, Wormald MR, Sim RB, Rudd PM, Dwek RA: The impact of glycosylation on the biological function and structure of human immunoglobulins. Annu Rev Immunol 2007, 25:21-50.

24. Lu R, Zhao X, Li J, Niu P, Yang B, Wu H, Wang W, Song H, Huang B, Zhu N: Genomic characterisation and epidemiology of 2019 novel coronavirus: implications for virus origins and receptor binding. The Lancet 2020, 395(10224):565-574.

25. Huang I, Lim MA, Pranata R: Diabetes mellitus is associated with increased mortality and severity of disease in COVID-19 pneumonia-A systematic review, meta-analysis, and meta-regression. Diabetes Metab Syndr 2020; 17;14(4):395-403

26. Chen Y, Gong X, Wang L, Guo J: Effects of hypertension, diabetes and coronary heart disease on COVID-19 diseases severity: a systematic review and meta-analysis. medRxiv 2020.

27. Zhou F, Yu T, Du R, Fan G, Liu Y, Liu Z, Xiang J, Wang Y, Song B, Gu X: Clinical course and risk factors for mortality of adult inpatients with COVID-19 in Wuhan, China: a retrospective cohort study. The lancet 2020.

28. Opal SM, Girard TD, Ely EW: The immunopathogenesis of sepsis in elderly patients. Clinical infectious diseases 2005, 41(Supplement_7):S504-S512.

29. Chen T, Wu D, Chen H, Yan W, Yang D, Chen G, Ma K, Xu D, Yu H, Wang H: Clinical characteristics of 113 deceased patients with coronavirus disease 2019: retrospective study. Bmj 2020, 368.

30. Muller L, Gorter K, Hak E, Goudzwaard W, Schellevis F, Hoepelman A, Rutten G: Increased risk of common infections in patients with type 1 and type 2 diabetes mellitus. Clinical infectious diseases 2005, 41(3):281288.

31. Sharma S, Ray A, Sadasivam B: Metformin in COVID-19: A Possible Role Beyond Diabetes. Diabetes Res Clin Pract. 2020; 30;164:108183

32. Pal R, Bhadada SK: Should anti-diabetic medications be reconsidered amid COVID-19 pandemic? Diabetes Res Clin Pract 2020, 163:108146-108146.

\section{Tables}


Table 1 Characteristics and disease-related symptoms in the study population on admission, overall and by survivor status

\begin{tabular}{lllll} 
Characteristics & Total & Non-survivors & Survivors & P-value \\
& $\mathbf{N}=\mathbf{4 5 5}$ & $\mathbf{N}=\mathbf{7 9}$ & $\mathbf{N = 3 7 6}$ & \\
\hline Age Mean $(\mathrm{SD})$ & $63.8(13.5)$ & $69.4(12.2)$ & $62.6(13.5)$ & $<0.001$ \\
\hline Age $\geq 65$ years, \% $(\mathrm{N})$ & $47.9 \%(218)$ & $65.8 \%(52)$ & $44.1 \%(166)$ & $<0.001$ \\
\hline Gender: Male, \% $(\mathrm{N})$ & $41.8 \%(190)$ & $49.4 \%(39)$ & $40.2 \%(151)$ & 0.131 \\
\hline Symptoms, \% $(\mathrm{N})$ & & & & \\
\hline Caught & $45.9 \%(209)$ & $36.7 \%(29)$ & $47.9 \%(180)$ & 0.070 \\
\hline Fever & $37.4 \%(170)$ & $39.2 \%(31)$ & $37.0(139)$ & 0.704 \\
\hline Shortness of breath & $56.7 \%(258)$ & $62.0 \%(49)$ & $55.6 \%(209)$ & 0.294 \\
\hline Tiredness & $23.3 \%(106)$ & $16.5 \%(13)$ & $24.7 \%(93)$ & 0.114 \\
\hline Lack of consciousness, \% $(\mathrm{N})$ & $5.7 \%(26)$ & $16.5 \%(13)$ & $3.5 \%(13)$ & $<0.001$ \\
\hline O2 saturation $<93 \%$ & $58.0 \%(264)$ & $88.6 \%(70)$ & $51.6 \%(194)$ & $<0.001$ \\
\% $(\mathrm{N})$ & & & &
\end{tabular}

\section{Comorbidities, \% ( $N$ )}

\begin{tabular}{|lllll}
\hline HTN & $54.0 \%(239)$ & $60.5 \%(46)$ & $52.6 \%(193)$ & 0.206 \\
\hline CVD & $43.7 \%(199)$ & $51.9 \%(41)$ & $42.0 \%(158)$ & 0.108 \\
\hline CKD & $22.2 \%(101)$ & $35.4 \%(28)$ & $19.4 \%(73)$ & 0.002 \\
\hline Other* & $10.1 \%(46)$ & $16.7 \%(13)$ & $8.8 \%(33)$ & $\mathbf{0 . 0 3 6}$ \\
\hline
\end{tabular}

Number of Comorbidities, \% (N)

\begin{tabular}{|c|c|c|c|c|}
\hline 0 & $30.5 \%$ (139) & $22.8 \%(18)$ & $32.2 \%(121)$ & $0.008 t$ \\
\hline 1 & $25.7 \%$ (117) & $21.5 \%(17)$ & $26.6 \%(100)$ & \\
\hline 2 & $29.5 \%$ (134) & $32.9 \%(26)$ & $28.7 \%(108)$ & \\
\hline$\geq 3$ & $14.3 \%(65)$ & $22.8 \%(18)$ & $12.5 \%(47)$ & \\
\hline \multicolumn{5}{|l|}{ Drug History } \\
\hline ACEls or ARBs & $42.9 \%(190)$ & $50.0 \%(38)$ & $41.4 \%(152)$ & 0.169 \\
\hline Statins & $28.9 \%(117)$ & $34.3 \%(24)$ & $27.8 \%(93)$ & 0.273 \\
\hline
\end{tabular}

ACEls= angiotensin-converting enzyme inhibitors. ARBs= angiotensin II receptor blockers. $C K D=$ Chronic Kidney diseases. $\mathrm{CVD}=$ Cardiovascular diseases. $\mathrm{HTN}=$ Hypertension. IQR=Inter quartile range. ICU=Intensive care unit

*Cancer, rheumatism, immunodeficiency, or chronic diseases of respiratory, liver, and blood 


\begin{tabular}{|c|c|c|c|c|}
\hline \multirow[t]{2}{*}{ Characteristics } & \multirow{2}{*}{$\begin{array}{l}\text { Total } \\
\text { Median (IQR*) }\end{array}$} & \multirow{2}{*}{$\begin{array}{l}\text { Non-survivors } \\
\text { Median (IQR*) }\end{array}$} & \multirow{2}{*}{$\begin{array}{l}\text { Survivors } \\
\text { Median (IQR*) }\end{array}$} & \multirow[t]{2}{*}{ P-value } \\
\hline & & & & \\
\hline WBC count, $\times 10^{9} / \mathrm{L}$ & $7.3(5.4,10.5)$ & $9.8(6.7-13.4)$ & $7.1(5.4-9.2)$ & 0.004 \\
\hline Lymphocyte count, $\times 10^{9} / \mathrm{L}$ & $2.01(1.21-2.87)$ & $1.14(0.78-1.8)$ & $2.25(1.52-2.87)$ & $<0.001$ \\
\hline Neutrophil count, $\times 10^{9} / \mathrm{L}$ & $7.29(6.22-8.23)$ & $8.34(7.70-8.71)$ & $7.00(6.20-7.75)$ & $<0.001$ \\
\hline AST, U/L & $36.0(26.0-51.0)$ & $33.5(20.25-54.0)$ & $29.0(18.0-43.0)$ & 0.087 \\
\hline$A L T, U / L$ & $30.0(18.0-43.5)$ & $45.5(31.0-83.0)$ & $34.0(25.0-46.5)$ & 0.118 \\
\hline Creatinine, mg/dl & $1.1(0.9-1.5)$ & $1.4(0.9-2.2)$ & $1.1(0.9-1.4)$ & 0.020 \\
\hline $\mathrm{LDH}, \mathrm{U} / \mathrm{L}$ & $474.0(356.7-629.4)$ & $674.0(487.0$ - 932.0) & $437.0(350.0-587.0)$ & 0.002 \\
\hline $\mathrm{Hb}, \mathrm{g} / \mathrm{dL}$ & 12.65 (11.30-14.1) & $12.1(10.9-13.3)$ & $12.8(11.6-14.1)$ & 0.008 \\
\hline Esr, mm/h & $44.5(23.75-75.0)$ & $43.5(29.5-84.0)$ & $44.5(22.0-74.5)$ & 0.872 \\
\hline CRP, mg/l & $25.0(7.0-73.0)$ & $53.8(21.0-79.0)$ & $25.0(5.75-72.0)$ & 0.015 \\
\hline Cpk, U/L & $88.5(58.4-151.0)$ & $115.0(70.0-222)$ & $81.7(58.0-150.0)$ & 0.016 \\
\hline Cpk-MB, IU/L & $22.0(15.0-30.0)$ & $27.4(19.0-40.3)$ & $20.0(14.0-29.0)$ & 0.019 \\
\hline $\mathrm{FBS}, \mathrm{mg} / \mathrm{dl}$ & $174(138.0-224)$ & $192.0(153.0-262.0)$ & $166.0(134.0-216.0)$ & 0.061 \\
\hline \multicolumn{5}{|l|}{ *IQR=Inter quartile range } \\
\hline \multicolumn{5}{|c|}{$\begin{array}{l}\text { ALT = Alanine transaminases. } \mathrm{AST}=\text { Aspartate transaminases. } \mathrm{CRP}=\mathrm{C}-\text {-reactive protein. } \mathrm{CPK}=\text { Creatine } \\
\text { phosphokinase. CK-MB=creatine kinase myocardial band, Esr= Erythrocyte sedimentation rate. FBS=fasting } \\
\text { blood sugar } \mathrm{Hb}=\text { Hemoglobin. } \mathrm{LDH} \text { : Lactate dehydrogenase. } \mathrm{PT}=\text { Prothrombin time. WBC=White blood cell }\end{array}$} \\
\hline
\end{tabular}




\begin{tabular}{|c|c|c|c|c|c|}
\hline Test & AUC $(95 \% \mathrm{Cl})$ & $\begin{array}{l}\mathrm{P}- \\
\text { value }\end{array}$ & $\begin{array}{l}\text { Optimal cutoff } \\
\text { point }\end{array}$ & $\begin{array}{l}\text { Sensitivity } \\
\%\end{array}$ & $\begin{array}{l}\text { Specificity } \\
\%\end{array}$ \\
\hline WBC count, $\times 10^{9} / \mathrm{L}$ & $0.66(0.59-0.73)$ & $<0.001$ & 8.1 & 60.0 & 61.7 \\
\hline $\begin{array}{l}\text { Lymphocyte count, } x \\
10^{9} / \mathrm{L}\end{array}$ & $0.75(0.68-0.81)$ & $<0.001$ & 1.51 & 72.1 & 70.3 \\
\hline Neutrophil count, $\times 10^{9} / \mathrm{L}$ & $0.76(0.69-0.82)$ & $<0.001$ & 8.0 & 67.2 & 74.3 \\
\hline $\mathrm{Hb}, \mathrm{g} / \mathrm{dL}$ & $0.61(0.54-0.68)$ & 0.003 & 12.5 & 64.3 & 57.2 \\
\hline Creatinine, $\mathrm{mg} / \mathrm{dl}$ & $0.60(0.52-0.69)$ & 0.010 & 1.36 & 52.0 & 74.6 \\
\hline AST, U/L & $0.64(0.53-0.74)$ & 0.010 & 39 & 61.1 & 62.4 \\
\hline$A L T, U / L$ & $0.57(0.47-0.68)$ & 0.151 & - & - & - \\
\hline $\mathrm{LDH}, \mathrm{U} / \mathrm{L}$ & $0.74(0.64-0.84)$ & $<0.001$ & 544 & 71.9 & 72.8 \\
\hline Cpk-MB, IU/L & $0.66(0.55-0.76)$ & 0.004 & 23 & 67.7 & 60.0 \\
\hline Cpk, U/L & $0.61(0.51-0.71)$ & 0.027 & 81.4 & 70.7 & 55.0 \\
\hline CRP, mg/l & $0.61(0.53-0.68)$ & 0.012 & 39.0 & 60.4 & 61.0 \\
\hline Esr, mm/h & $\begin{array}{l}0.55(0.46- \\
0.64)\end{array}$ & 0.287 & - & - & - \\
\hline $\mathrm{FBS}, \mathrm{mg} / \mathrm{dl}$ & $0.62(0.53-0.70)$ & 0.006 & 179 & 60.0 & 57.0 \\
\hline
\end{tabular}




\begin{tabular}{|c|c|c|c|c|c|c|c|}
\hline \multirow{3}{*}{$\begin{array}{l}\text { lass } \\
\text { Demographic } \\
\text { and clinical } \\
\text { characteristic }\end{array}$} & \multicolumn{7}{|c|}{$\begin{array}{l}\text { Table } 4 \text { Predicting factors for death of the COVID-19 in patients with diabetes mellitus (DM): } \\
\text { Logistic Regression Analysis }\end{array}$} \\
\hline & \multirow[t]{4}{*}{ Variable } & \multirow{2}{*}{\multicolumn{2}{|c|}{ Need to ICU }} & \multirow{3}{*}{\multicolumn{2}{|c|}{$\begin{array}{l}\text { Being ventilated } \\
\text { during } \\
\text { hospitalization } \\
\mathrm{N}=65\end{array}$}} & \multirow{3}{*}{\multicolumn{2}{|c|}{$\begin{array}{l}\text { Death } \\
N=79\end{array}$}} \\
\hline & & & & & & & \\
\hline & & & & & & & \\
\hline & & $\begin{array}{l}\text { Crude } \\
\text { OR } \\
\text { OR }(95 \% \\
\text { Cl) }\end{array}$ & $\begin{array}{l}\text { Adjusted§ } \\
\text { OR(95\% } \\
\mathrm{Cl})\end{array}$ & $\begin{array}{l}\text { Crude } \\
\text { OR } \\
\text { OR( }(95 \% \\
\text { Cl) }\end{array}$ & $\begin{array}{l}\text { Adjusted§ } \\
\text { OR(95\% } \\
\mathrm{Cl})\end{array}$ & $\begin{array}{l}\text { Crude } \\
\text { OR } \\
\text { OR(95\% } \\
\text { Cl) }\end{array}$ & $\begin{array}{l}\text { Adjusted§ } \\
\text { OR( }(95 \% \\
\mathrm{Cl})\end{array}$ \\
\hline & Age $(\geq 65 /<65)$ & $\begin{array}{l}2.34 \\
(1.48- \\
3.72)\end{array}$ & $\begin{array}{l}1.72 \\
(1.02- \\
2.94)\end{array}$ & $\begin{array}{l}2.40 \\
(1.38- \\
4.17)\end{array}$ & $\begin{array}{l}2.40 \\
(1.35- \\
4.28)\end{array}$ & $\begin{array}{l}2.44 \\
(1.47- \\
4.05)\end{array}$ & $\begin{array}{l}2.0(1.16- \\
3.44)\end{array}$ \\
\hline & $\operatorname{Sex}(M / F)$ & $\begin{array}{l}1.24 \\
(0.79- \\
1.95)\end{array}$ & - & $\begin{array}{l}1.42 \\
(0.84- \\
2.41)\end{array}$ & - & $\begin{array}{l}1.45 \\
(0.85- \\
2.36)\end{array}$ & - \\
\hline & \multicolumn{7}{|l|}{ Comorbidities } \\
\hline & HTN & $\begin{array}{l}1.75 \\
(1.10- \\
2.80)\end{array}$ & - & $\begin{array}{l}1.15 \\
(0.67- \\
1.96)\end{array}$ & - & $\begin{array}{l}1.38 \\
(0.84- \\
2.29)\end{array}$ & - \\
\hline & CVD & $\begin{array}{l}1.89 \\
(1.21- \\
2.97)\end{array}$ & - & $\begin{array}{l}1.86 \\
(1.09- \\
3.19)\end{array}$ & - & $\begin{array}{l}1.49 \\
(0.91- \\
2.42)\end{array}$ & - \\
\hline & CKD & $\begin{array}{l}2.30 \\
(1.41- \\
3.77)\end{array}$ & - & $\begin{array}{l}2.58 \\
(1.48- \\
4.52)\end{array}$ & $\begin{array}{l}2.09 \\
(1.16- \\
3.75)\end{array}$ & $\begin{array}{l}2.27 \\
(1.34- \\
3.86)\end{array}$ & $\begin{array}{l}2.05 \\
(1.16 \\
-3.62)\end{array}$ \\
\hline & $\begin{array}{l}\text { Other } \\
\text { comorbidity* }\end{array}$ & $\begin{array}{l}2.40 \\
(1.26- \\
4.59)\end{array}$ & - & $\begin{array}{l}2.42 \\
(1.18- \\
4.96)\end{array}$ & - & $\begin{array}{l}2.08 \\
(1.04- \\
4.16)\end{array}$ & $\begin{array}{l}2.20 \\
(1.04- \\
4.63)\end{array}$ \\
\hline & \multicolumn{7}{|c|}{ Number of co. ; Reference category: No comorbidity } \\
\hline & 1 & $\begin{array}{l}1.88 \\
(0.94- \\
3.76)\end{array}$ & $\begin{array}{l}1.61 \\
(0.72- \\
3.60)\end{array}$ & $\begin{array}{l}1.21 \\
(0.52- \\
2.80)\end{array}$ & - & $\begin{array}{l}1.14 \\
(0.56- \\
2.33)\end{array}$ & - \\
\hline & 2 & $\begin{array}{l}2.61 \\
(1.36- \\
5.0)\end{array}$ & $\begin{array}{l}2.23 \\
(1.04 \\
-4.78)\end{array}$ & $\begin{array}{l}2.42 \\
(1.16- \\
5.06)\end{array}$ & - & $\begin{array}{l}1.62 \\
(0.84- \\
3.11)\end{array}$ & - \\
\hline & $\geq 3$ & $\begin{array}{l}4.80 \\
(2.33- \\
9.88)\end{array}$ & $\begin{array}{l}4.08 \\
(1.78 \\
-9.34)\end{array}$ & $\begin{array}{l}3.46 \\
(1.52- \\
7.83)\end{array}$ & - & $\begin{array}{l}2.57 \\
(1.23- \\
5.37)\end{array}$ & - \\
\hline & \multicolumn{7}{|l|}{ Drug history } \\
\hline & $\begin{array}{l}\text { ACEls or ARBs } \\
\text { (yes/no) }\end{array}$ & $\begin{array}{l}1.70 \\
(1.08- \\
2.67)\end{array}$ & - & $\begin{array}{l}1.45 \\
(0.86- \\
2.46)\end{array}$ & - & $\begin{array}{l}1.41 \\
(0.86- \\
2.32)\end{array}$ & - \\
\hline & Statins(yes/no) & $\begin{array}{l}1.76 \\
(1.01- \\
2.76)\end{array}$ & - & $\begin{array}{l}1.10 \\
(0.61- \\
1.99)\end{array}$ & - & $\begin{array}{l}1.35 \\
(0.78- \\
2.35)\end{array}$ & - \\
\hline
\end{tabular}


Laboratory Hematological, Biochemistry and Isoenzymes parameters

finding,

\begin{tabular}{|c|c|c|c|c|c|c|}
\hline 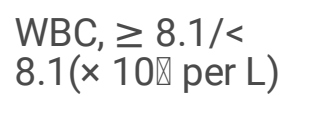 & $\begin{array}{l}2.27 \\
(1.41- \\
3.67)\end{array}$ & - & $\begin{array}{l}2.56 \\
(1.46- \\
4.47)\end{array}$ & - & $\begin{array}{l}2.36 \\
(1.39- \\
3.99)\end{array}$ & - \\
\hline $\begin{array}{l}\text { Lymphocyte, } \\
<1.51 / \geq 1.51 \text { (× } \\
10 \varangle / L)\end{array}$ & $\begin{array}{l}4.33 \\
(2.60 \\
-7.19)\end{array}$ & $\begin{array}{l}2.28 \\
(1.01- \\
5.15)\end{array}$ & $\begin{array}{l}4.67 \\
(2.59- \\
8.47)\end{array}$ & - & $\begin{array}{l}5.84 \\
(3.27- \\
10.44)\end{array}$ & - \\
\hline $\begin{array}{l}\text { Neutrophil, } \geq 8.0 \\
/<8.0(\times 10 \otimes / L))\end{array}$ & $\begin{array}{l}4.55 \\
(2.74- \\
7.57)\end{array}$ & $\begin{array}{l}2.32 \\
(1.04 \\
-5.24)\end{array}$ & $\begin{array}{l}5.02 \\
(2.82- \\
8.93)\end{array}$ & $\begin{array}{l}5.00 \\
(2.82- \\
8.94)\end{array}$ & $\begin{array}{l}6.65 \\
(3.75- \\
11.80)\end{array}$ & $\begin{array}{l}6.62 \\
(3.73- \\
11.75)\end{array}$ \\
\hline $\begin{array}{l}\mathrm{Hb},<12.5 /> \\
12.5(\mathrm{~g} / \mathrm{dl})\end{array}$ & $\begin{array}{l}2.38 \\
(1.45- \\
3.88)\end{array}$ & $\begin{array}{l}2.03 \\
(1.20- \\
3.43)\end{array}$ & $\begin{array}{l}1.87 \\
(1.04- \\
3.15)\end{array}$ & - & $\begin{array}{l}2.21 \\
(1.30- \\
3.77)\end{array}$ & $\begin{array}{l}2.05 \\
(1.13- \\
3.72)\end{array}$ \\
\hline $\begin{array}{l}\text { AST, } \geq 39 /<39 \\
\left(\mathrm{U} / \mathrm{L}^{\prime}\right)\end{array}$ & $\begin{array}{l}2.32 \\
(1.46- \\
5.46)\end{array}$ & $\begin{array}{l}2.39 \\
(1.12- \\
5.13)\end{array}$ & $\begin{array}{l}2.65 \\
(1.26 \\
-5.61)\end{array}$ & $\begin{array}{l}2.40 \\
(1.25 \\
-5.69)\end{array}$ & $\begin{array}{l}2.62 \\
(1.26- \\
5.44)\end{array}$ & - \\
\hline $\begin{array}{l}\text { Creatinine, } \\
\geq 1.36 /<1.36 \\
(\mathrm{mg} / \mathrm{dl})\end{array}$ & $\begin{array}{l}2.57 \\
(1.55- \\
4.24)\end{array}$ & $\begin{array}{l}2.67 \\
(1.25- \\
5.58)\end{array}$ & $\begin{array}{l}2.63 \\
(1.49- \\
4.66)\end{array}$ & $\begin{array}{l}2.64 \\
(1.12- \\
6.21)\end{array}$ & $\begin{array}{l}3.18 \\
(1.83- \\
5.53)\end{array}$ & $\begin{array}{l}3.10 \\
(1.38- \\
6.98)\end{array}$ \\
\hline $\begin{array}{l}\mathrm{CRP}, \geq 39 /<39 \\
(\mathrm{mg} / \mathrm{dl})\end{array}$ & $\begin{array}{l}1.65 \\
(0.96- \\
2.81)^{\ddagger}\end{array}$ & - & $\begin{array}{l}1.30 \\
(0.70- \\
2.40)\end{array}$ & - & $\begin{array}{l}2.22 \\
(1.25- \\
3.94)\end{array}$ & - \\
\hline $\begin{array}{l}\mathrm{FBS}, \geq 179 /<179 \\
(\mathrm{mg} / \mathrm{dl})\end{array}$ & $\begin{array}{l}1.72 \\
(1.03 \\
-2.88)\end{array}$ & - & $\begin{array}{l}1.63 \\
(0.89- \\
2.95)\end{array}$ & - & $\begin{array}{l}1.72 \\
(0.97- \\
3.05)\end{array}$ & - \\
\hline $\begin{array}{l}\text { LDH, } \\
\geq 544 /<544(\mathrm{U} / \mathrm{L})\end{array}$ & $\begin{array}{l}4.0(1.95- \\
8.17)\end{array}$ & $\begin{array}{l}4.31 \\
(1.36 \\
-13.68)\end{array}$ & $\begin{array}{l}3.74 \\
(1.64- \\
8.49)\end{array}$ & $\begin{array}{l}3.45 \\
(1.36- \\
9.27)\end{array}$ & $\begin{array}{l}7.04 \\
(3.05 \\
-16.26)\end{array}$ & $\begin{array}{l}6.53 \\
(2.51- \\
16.97)\end{array}$ \\
\hline $\begin{array}{l}\text { Cpk, } \\
\geq 81.4 /<81.4(\mathrm{U} / \mathrm{L})\end{array}$ & $\begin{array}{l}2.54 \\
(1.25- \\
5.18)\end{array}$ & $\begin{array}{l}3.67 \\
(0.96- \\
14.23)\end{array}$ & $\begin{array}{l}2.78 \\
(1.23- \\
6.27)\end{array}$ & - & $\begin{array}{l}2.44 \\
(1.17- \\
5.09)\end{array}$ & - \\
\hline $\begin{array}{l}\text { Cpk-MB, } \\
\geq 23 /<23(\mathrm{IU} / \mathrm{L})\end{array}$ & $\begin{array}{l}3.09 \\
(1.45- \\
6.56)\end{array}$ & - & $\begin{array}{l}2.69 \\
(1.12- \\
6.06)\end{array}$ & - & $\begin{array}{l}3.18 \\
(1.47 \\
-6.89)\end{array}$ & - \\
\hline
\end{tabular}

tP- value $<0.05 \neq P$ - value $<0.20$; $\S$ in each class, all variables with $p<0.2$ in the univariaite model were included in multivariate model.

$\mathrm{OR}=$ Odds Ratio. $\mathrm{Cl}=$ Confidence Interval;

ACEIs= angiotensin-converting enzyme inhibitors. ARBs= angiotensin II receptor blockers. $\mathrm{CKD}=$ Chronic Kidney diseases. $\mathrm{CVD}=$ Cardiovascular diseases. $\mathrm{HTN}=$ Hypertension. $\mathrm{ICU}=$ Intensive care unit. 
$\mathrm{ALT}=$ Alanine transaminases. $\mathrm{AST}=\mathrm{Aspartate}$ transaminases. $\mathrm{CRP}=\mathrm{C}$-reactive protein. $\mathrm{CPK}=$ Creatine phosphokinase. $\mathrm{CK}-\mathrm{MB}=$ creatine kinase myocardial band, Esr= Erythrocyte sedimentation rate. FBS=fasting blood sugar $\mathrm{Hb}=$ Hemoglobin. $\mathrm{LDH}$ : Lactate dehydrogenase. $\mathrm{PT}=$ Prothrombin time. $\mathrm{WBC}=$ White blood cell

Figures

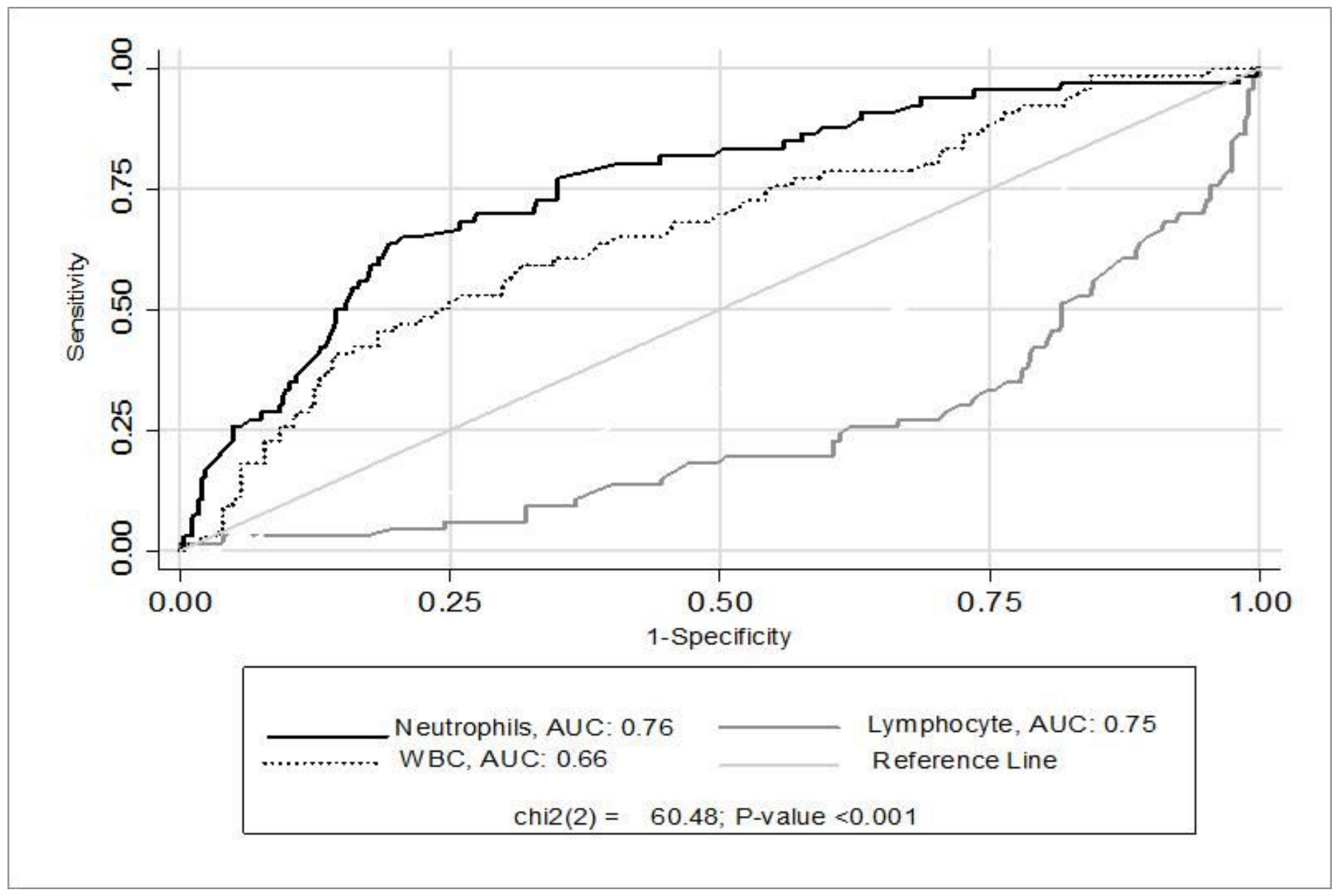

Figure 1

Receiver operating characteristic curves of Hematologic parameters for predicting COVID- 19 death. 


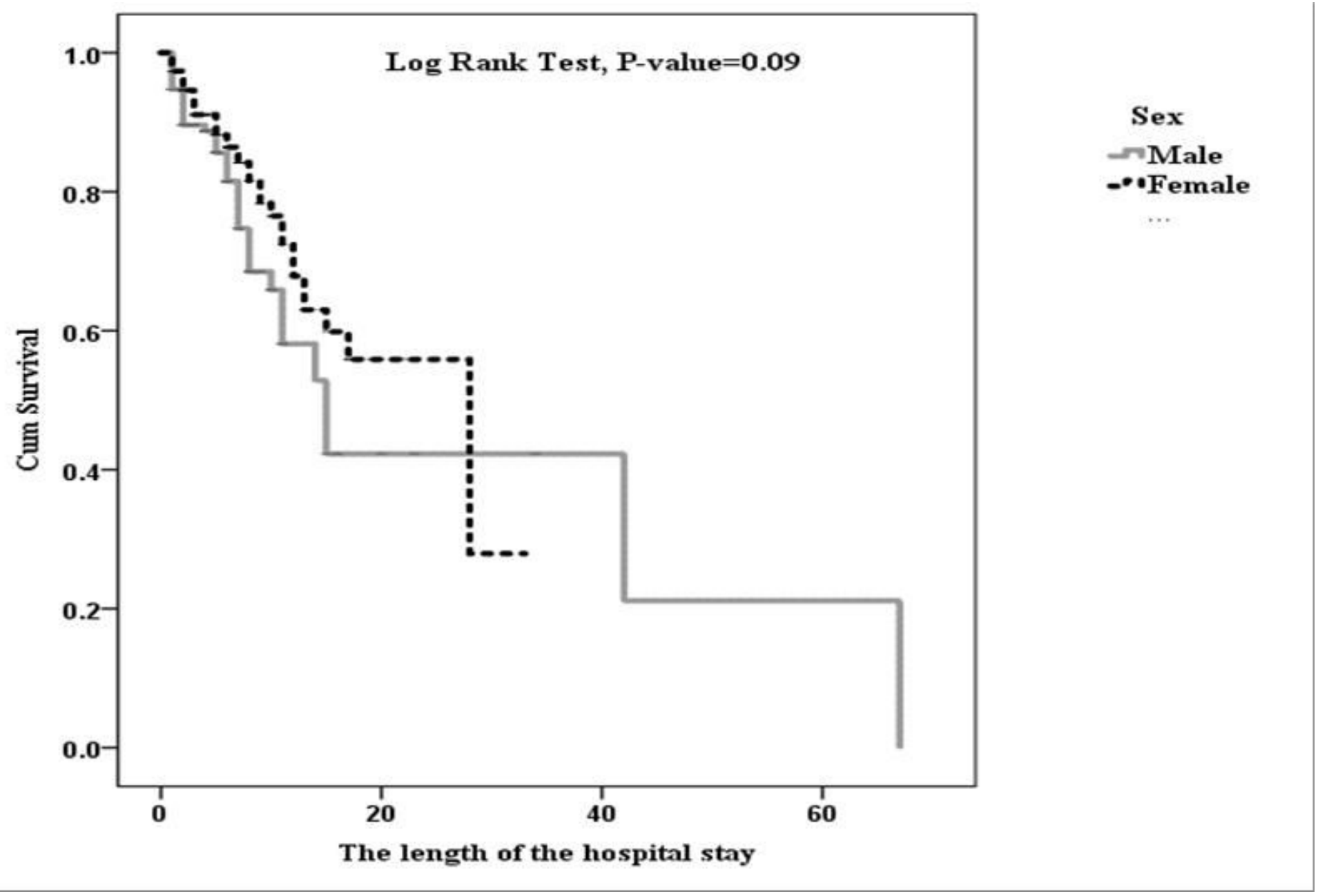

Figure 2

Survival Curve in Diabetic Patients with COVID-19 by gender status (Kaplan Meier \& log rank test) 


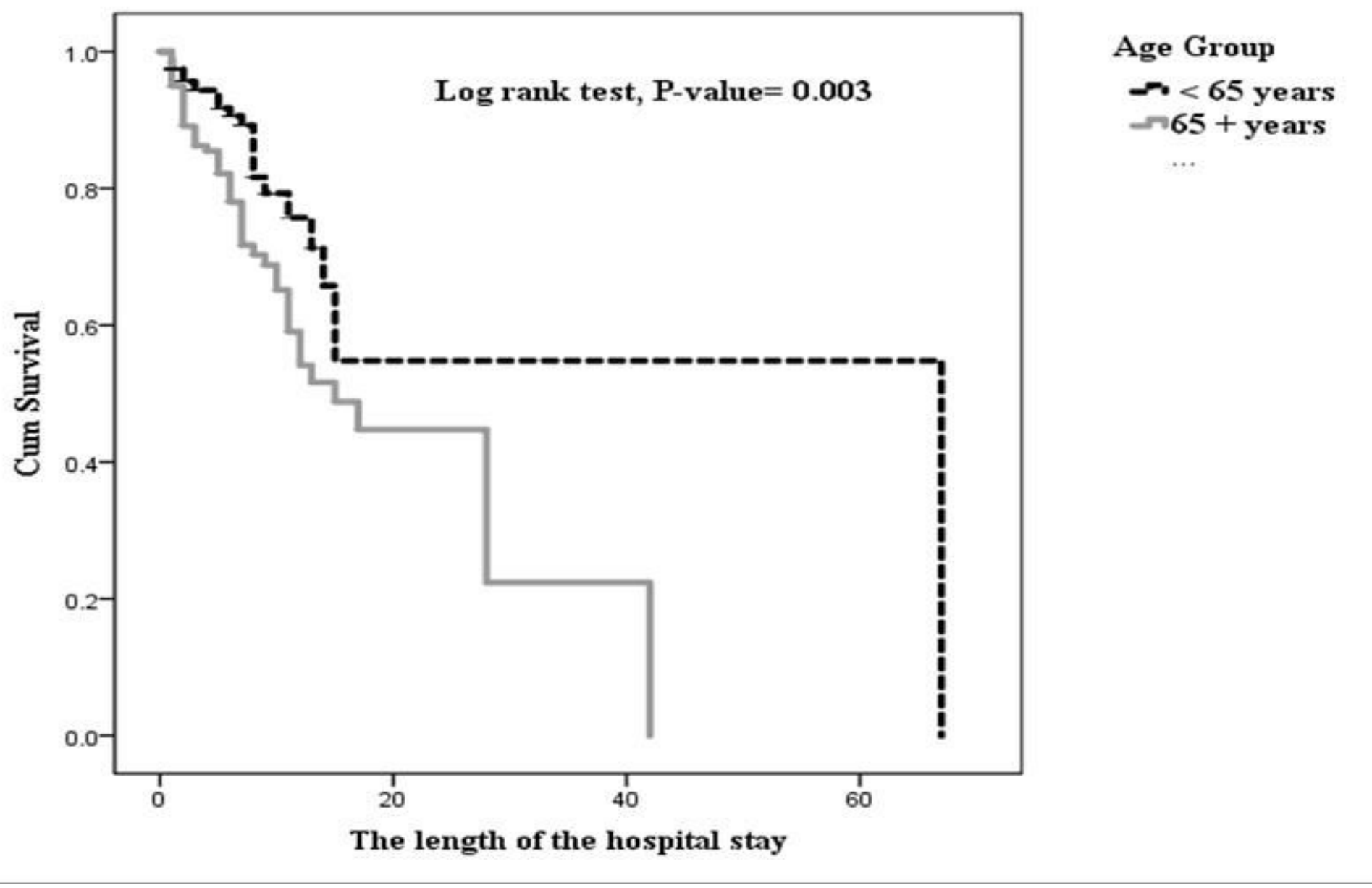

Figure 3

Survival Curve in Diabetic Patients with COVID-19 by Age - group (Kaplan Meier\& log rank test) 